PF 2020 (75/1): 479-500

https://doi.org/10.32798/pf.669

\author{
ELŻBIETA WIERZBICKA-PIOTROWSKA \\ Instytut Języka Polskiego \\ Uniwersytet Warszawski, Warszawa \\ e-mail: elzbieta.piotrowska@uw.edu.pl \\ ORCID 0000-0002-2310-2814
}

\title{
WPŁYW PREFIKSACJI NA WALENCJE POLSKICH CZASOWNIKÓW
}

\section{THE INFLUENCE OF PREFIXATION ON THE VALENCE OF POLISH VERBS}

\begin{abstract}
The article describes all the changes in valence patterns caused by prefixing in Polish. The analysis of several hundred verbs allowed to distinguish among them those that inherit the valence scheme from their word-formation bases, and 9 types of derivatives that change their valence requirements after adding a prefix to them. These changes concern the number of opened positions, their configuration and morphological form. Their source is most often the meaning introduced by the prefix into the semantic structure of ta verb, or the type of the prefix distinguished according to the grammatical case imposed by this prefix.
\end{abstract}

KEYWORDS: verb, rection, meaning

SŁOWA KLUCZOWE: czasownik, rekcja, znaczenie

Prefiksacja to zjawisko typowe dla czasowników słowiańskich, które znajdowało w literaturze przedmiotu liczne interpretacje gramatyczne oraz semantyczne. Opisując funkcje prefiksów tworzących nowe verba w polszczyźnie, autorzy zwracali uwagę głównie na modyfikacje znaczeniowe czasownika wywołane prefiksem, w mniejszym natomiast stopniu na typ zmian formalnych wywołanych prefiksacją (por. m.in. Agrell 1918; Bogusławski 1963; Śmiech 1986; Wróbel 1976, 1978, 1998). Nowym wymaganiom składniowym wprowadzanym przez prefiks były - co prawda - poświęcone fragmenty prac dotyczących charakterystyki 
syntaktycznej wybranych grup czasowników (por. Gołąb 1967; Krupianka 1969; Kudra 1993; Szupryczyńska 1973) oraz prace o charakterze glottodydaktycznym, w których zmiany łączliwości czasownika wywołane dodaniem do niego przedrostka były wskazywane jako sprawiające problemy uczącym się języka polskiego jako obcego, jednak także w tych pracach na ogół poprzestawano na stwierdzeniu faktu, że po dodaniu niektórych prefiksów zmienia się rekcja czasownika, rzadko natomiast podejmowano próbę wyjaśnienia mechanizmów leżących u podłoża takich zmian. (por. m.in. Bartnicka 1990). Do wyjątków pod tym względem należy praca Danuty Buttler z 1976 r. Innowacje składniowe współczesnej polszczyzny, w której autorka starała się uzasadnić każdą taką zmianę przesunięciami w obrębie pól leksykalnych, wywołanymi prefiksem. Pisała:

Nie ulega wątpliwości, że związki syntaktyczne czasowników prefiksalnych mają charakter najbardziej „uporządkowany” i że właśnie w tym zakresie działa ze szczególną wyrazistością ogólna tendencja do korelacji zjawisk z różnych płaszczyzn języka, tu przejawiająca się jako dążność do związania z pewnymi typami słowotwórczymi stałych zdolności konotacyjnych. (s. 82)

Analiza przeprowadzona w artykule potwierdza tezę przedstawioną w pracy, zgodnie z którą na zmianę schematu walencyjnego czasowników prefiksalnych ma wpływ zarówno rodzaj prefiksu, jak również znaczenie dodawane za jego pośrednictwem do podstawy słowotwórczej. W rezultacie nowo powstały derywat zostaje włączony do nowego pola leksykalnego, często z zupełnie innymi wymaganiami konotacyjnymi.

\section{Cel badań i zastosowana metoda}

$\mathrm{W}$ artykule zostanie podjęta próba ujęcia różnych rodzajów zmian w łączliwości czasownika, jakie wprowadza prefiksacja. Ze względu na ograniczoną objętość opracowania nie zostanie w nim jednak sformułowana wyczerpująca odpowiedź na liczne pytania, które pojawiają się w związku z podjętą problematyką, a mianowicie: jaka jest skala zjawiska oddziaływania prefiksacji na walencję polskich czasowników, czy dotyczy ono wszystkich leksemów, czy tylko wybranych grup, czy zmiany te są podporządkowane jakimś regułom o charakterze kategorialnym, czy są zjawiskami indywidualnymi. Celem analizy będzie wyłącznie wskazanie wszystkich wywołanych prefiksacją zmian formy składników konotowanych przez derywat w stosunku do czasownika bazowego i ich związku z określonymi przesunięciami semantycznymi w obrębie klasy czasowników. Ważne będzie także sprawdzenie - na tyle, na ile pozwoli na to materiał - czy poszczególne typy słowotwórcze powstające $\mathrm{w}$ wyniku prefiksacji są nadal produktywne, czy nowe czasowniki tworzone za pomocą prefiksu należą do tych samych pól 
semantycznych, co te powstałe w przeszłości, i czy modyfikacje znaczeniowe wywołane prefiksacją powodują obecnie podobne zmiany walencji, jak te, które obserwujemy w derywatach mających swoje ustalone już miejsce w systemie leksykalnym polszczyzny.

\section{Prezentacja materiału badawczego}

Jako punkt wyjścia rozważań potraktowaliśmy wyniki badań Witolda Śmiecha, opartych na bogatym materiale językowym, pochodzącym głównie ze SJPDor. oraz innych opracowań leksykograficznych. Opisując zmiany znaczeniowe wywołane przez 17 prefiksów tworzących w różnych okresach historii języka polskiego nowe formacje słowotwórcze, autor wyróżnił kilkadziesiąt typów słowotwórczych o wyraźnym znaczeniu strukturalnym, wywołanym prefiksem (Śmiech 1986). Uwzględniliśmy także prace Henryka Wróbla poświęcone zjawisku prefiksacji, zwłaszcza rozważania autora zawarte w Gramatyce wspótczesnego języka polskiego, które stanowiły zwieńczenie jego badań nad polskimi derywatami czasownikowymi (Wróbel 1976, 1978, 1998). Materiał wykorzystany $\mathrm{w}$ wymienionych pracach okazał się wystarczający, aby potwierdzić, że w języku polskim prefiksacja może nie mieć wpływu na zmianę schematów walencyjnych czasownika, jednak może też je zmieniać w różnorodny sposób. Potwierdził również twierdzenie D. Buttler, że zmiany te, jeśli się pojawiają, mają podłoże nie tylko formalne, będące wynikiem dodania określonego prefiksu, ale przede wszystkim semantyczne.

Ciekawe wydawało się więc zbadanie, które rodzaje zmian walencji występują w nowo powstających formacjach czasownikowych i czy reprezentowane przez nie typy słowotwórcze są produktywne także dzisiaj. Aby to sprawdzić, wykorzystaliśmy dodatkowo materiał pochodzący z pracy P. Wierzchonia (2007), czyli 437 nowych derywatów czasownikowych, powstałych w wyniku prefiksacji, oraz $\mathrm{z}$ artykułów, w których są analizowane nowe formacje słowotwórcze występujące w publicystyce, na forach internetowych oraz $\mathrm{w}$ tekstach potocznych (Kudra 1995, Wiśnicki 2009, Wtorkowska 2004, Stawnicka 2019). Dodaliśmy do nich ok. 100 nowych czasowników, które wyekscerpowaliśmy ze stron internetowych (głównie blogów i wypowiedzi na różnego rodzaju forach), nie odnotowanych przez autorów wymienionych prac i nieobecnych we współczesnych słownikach języka polskiego. Otrzymany w ten sposób materiał okazał się wystarczająco duży, aby móc pokusić się o przedstawienie w ogólnych zarysach wpływu prefiksacji na walencję polskich czasowników. 


\section{Prefiksacja czasownika a jego walencja}

Uwzględnione przez nas czasownikowe derywaty prefiksalne udało się w wyniku analizy podzielić na 10 grup, z których każda charakteryzuje się innymi wymaganiami walencyjnymi wchodzących w jej skład leksemów niż te wynikające z modelu walencji ich podstaw słowotwórczych.

Podział ma charakter czysto składniowy - braliśmy w nim pod uwagę wyłącznie rekcję poszczególnych formacji prefiksalnych i ich czasowników bazowych. Powstałą w ten sposób klasyfikację różnych wpływów prefiksacji na walencję polskich czasowników przedstawia poniższy wykres.

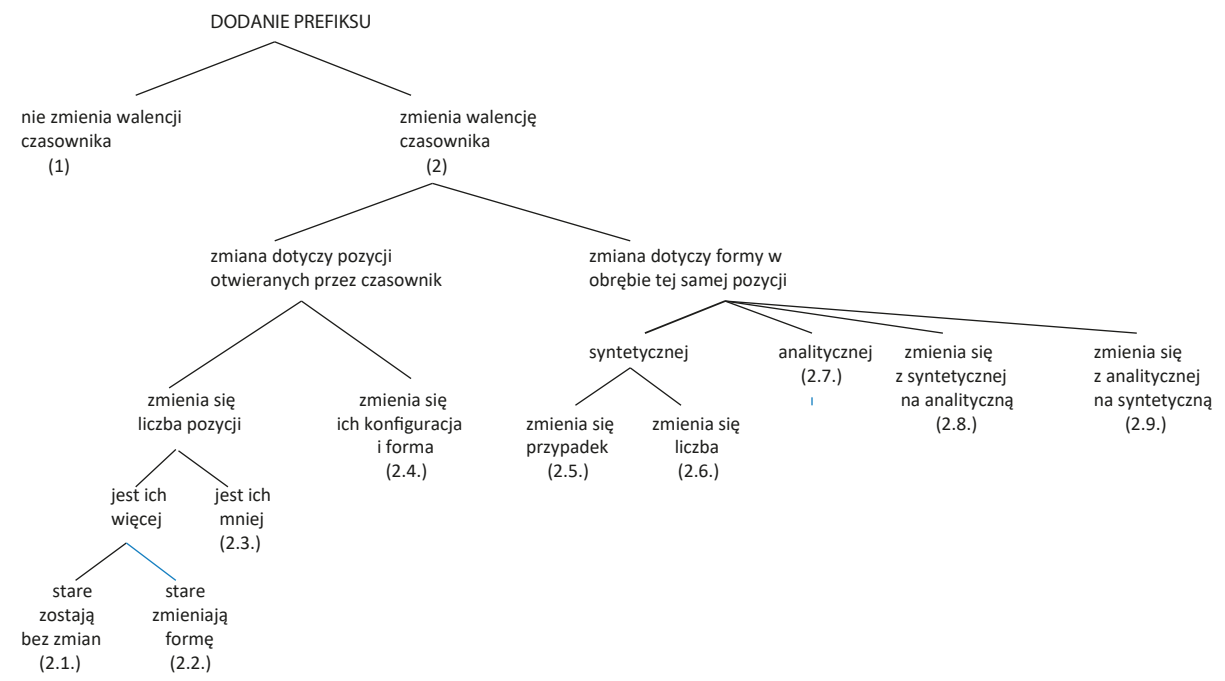

Klasyfikacja przedstawiona na wykresie wywołuje nieuchronnie pytanie dotyczące przyczyn zaobserwowanych zmian walencji, jakie powoduje prefiksacja w większości wyodrębnionych grup. Niewątpliwie pierwsza nasuwająca się odpowiedź kieruje badacza ku zależności między funkcją pełnioną przez określony prefiks a walencją utworzonego przez ten prefiks derywatu. Jednak 3 wymieniane w literaturze przedmiotu funkcje prefiksów czasownikowych: zmiana znaczenia podstawy (np. zszyć - 'połączyć coś z czymś, szyjąc'), jego modyfikacja ze względu na okoliczności, w jakich odbywa się czynność (np. obsmażyć - 'smażyć coś dookoła') oraz zmiana aspektu z niedokonanego na dokonany (np. zrobić - 'skończyć robić') z wyjątkiem ostatniej z wymienionych nie wpływają na walencję tworzonych przez nie derywatów.

Zmiany wymagań derywatów czasownikowych w stosunku do wymagań ich podstaw słowotwórczych są natomiast $\mathrm{w}$ większym stopniu uzależnione od znaczenia wprowadzanego przez prefiks. Każda modyfikacja semantyczna wiąże się 
bowiem z użyciem określonego prefiksu w określonej funkcji semantycznej i narzucaniem nowo utworzonemu czasownikowi określonej rekcji, np. ablatywność z użyciem typowego dla niej prefiksu od- i otwieraniem miejsca dla wyrażenia przyimkowego $z+$ gen, a tranzytywność z użyciem różnych prefiksów, tworzących czasowniki, które obligatoryjnie łączą się z wyrażeniem przyimkowym przez + acc. Jednak za żadną z takich modyfikacji nie jest $\mathrm{w}$ języku polskim odpowiedzialny wyłącznie jeden prefiks, a $z$ drugiej strony każdy prefiks jest w języku polskim polisemiczny i zdarza się, że w każdym ze swoich znaczeń narzuca czasownikowi inny schemat walencyjny, np. prefiks prze- tworzy kilka typów słowotwórczych:

przegrać - 'stracić coś, grając'

przekopać - 'spulchnić ziemię, kopiąc ją na określonej powierzchni'

przepłacić - 'płacić za dużo w stosunku do normy'

przeczytać - 'skończyć czytać'

Skoro więc nie można wyłącznie prefiksu obarczyć odpowiedzialnością za walencję czasownika, konieczne wydaje się spojrzenie także na sam czasownik, w szczególności na jego nowe znaczenie wywołane prefiksacją, które powoduje, że przechodzi on do innego pola leksykalnego, narzucającego nie tylko określone wymagania semantyczne, ale także syntaktyczne. Okazuje się, że w sytuacji, kiedy znaczenie prefiksu nie współgra $z$ charakterystyką walencyjną czasowników należących do pola, do którego zostaje włączony czasownik prefiksalny, zmienia on swoją rekcję, tak aby pojawiła się zgodność funkcjonalna między prefiksem a wymaganym przez czasownik przypadkiem.

Na zależności tego typu zwróciła uwagę D. Buttler (1976), sugerując, że są podstawą polskiej gramatyki leksykalnej, stanowiącej zdaniem autorki ważną część systemu każdego z języków naturalnych. Jako przyczynek do przyszłych prac nad taką gramatyką może posłużyć przegląd tych zależności w obrębie każdej z grup wyodrębnionych w artykule. Opisując derywaty wchodzące w ich skład, wybieraliśmy z bogatego zestawu typów słowotwórczych czasownika tylko niektóre, potwierdzające odrębność danej grupy z punktu widzenia wpływu prefiksacji na jej charakterystykę walencyjną.

\subsection{Brak zmian walencji $w$ wyniku prefiksacji}

Ponad 50\% badanych czasowników prefiksalnych zachowuje właściwości walencyjne swojej podstawy słowotwórczej. Dzieje się tak m.in. wtedy, kiedy funkcją prefiksu jest wyłącznie zmiana aspektu z niedokonanego na dokonany, np.

tłumaczyć coś komuś $\rightarrow$ wytłumaczyć coś komuś

prosić kogoś o coś $\rightarrow$ poprosić kogoś o coś 
Oprócz tego dziedziczy walencję po swojej podstawie słowotwórczej wiele czasowników, w których przedrostek wprowadza oprócz zmiany aspektu jeszcze dodatkowe modyfikacje znaczenia, np.

uczyć kogoś czegoś $\rightarrow$ wyuczyć kogoś czegoś, oduczyć kogoś czegoś

śpiewać coś $\rightarrow$ zaśpiewać coś, wyśpiewać coś, odśpiewać coś,

kopać coś $\rightarrow$ przekopać coś, wykopać coś

Dotyczy to m.in. modyfikacji temporalnej znaczenia czasownika, np. przez prefiks po, który wprowadza znaczenie:

- trwania czynności przez pewien krótki czas, np.

czytać $\rightarrow$ poczytać

leżeć $\rightarrow$ poleżeć

spać $\rightarrow$ pospać

- jednorazowości czynności, np.

witać $\rightarrow$ powitać

żegnać $\rightarrow$ pożegnać

chwalić $\rightarrow$ pochwalić

Nie zmienia walencji czasownika także prefiks pod-, modyfikując jego znaczenie przez wprowadzenie komponentu semantycznego:

- usytuowania akcji poniżej jakiegoś przedmiotu, np.

pisać pismo $\rightarrow$ podpisać pismo

kleić kopertę $\rightarrow$ podkleić kopertę

- ruchu z dołu do góry, np.

nieść wiadro $\rightarrow$ podnieść wiadro

rzucić piłkę $\rightarrow$ podrzucić piłkę

- zbliżania się do czegoś, np.

biec do czegoś $\rightarrow$ podbiec do czegoś

prowadzić pod szkołę $\rightarrow$ podprowadzić pod szkołę

- częściowego osiągnięcia celu lub skutku czynności, np.

leczyć pacjenta $\rightarrow$ podleczyć pacjenta

suszyć grzyby $\rightarrow$ podsuszyć grzyby

uczyć kursantów $\rightarrow$ poduczyć kursantów

Niektóre prefiksy, np. za-, z-, po- zmieniają znaczenie czasownika bazowego, nie zmieniają jednak jego wymagań walencyjnych, np.

czytać książkę $\rightarrow$ zaczytać książkę 
nosić ubranie $\rightarrow$ znosić ubranie

kochać kogoś $\rightarrow$ pokochać kogoś

kochać się w kimś $\rightarrow$ zakochać się w kimś

Jak się okazuje, lista prefiksów, które przynajmniej w jednej ze swoich funkcji semantycznych nie powodują zmian walencyjnych, obejmuje wszystkie polskie prefiksy, co nie oznacza, że w pozostałych swoich funkcjach takich zmian nie wprowadzają. Czasami zresztą to dziedziczenie walencji po swojej podstawie słowotwórczej jest czysto formalne, bo chociaż czasownik z prefiksem otwiera miejsce dla rzeczownika w tym samym przypadku, to jednak semantycznie rzeczownik ten odnosi się za każdym razem do innego argumentu, np. rzeczownik w bierniku przy czasowniku bazowym od kopać jest nazwą różnych obiektów, która może odnosić się zarówno do typu podłoża, np. kopać ziemię, jak również do przewidywanego rezultatu czynności, np. kopać grób, natomiast derywat przekopać do rodzaju terenu, na którym czynność jest wykonywana, np. przekopać ogród, przekopać grządkę. Jeszcze inaczej jest w wypadku derywatu wykopać, którego biernikowe uzupełnienie to przede wszystkim nazwy efektów kopania, nie tylko odnoszące się do kształtu wykonanego otworu, np. wykopać dół, lecz także do przedmiotów, które mogą zostać wykopane, np. wykopać skrzynkę z amunicja, ale nie do rodzaju terenu, np. *wykopać grządkę.

Tego typu zmiany łączliwości leksykalnej wywołane prefiksacją zostały w minimalnym tylko stopniu uwzględnione $\mathrm{w}$ artykule jako charakterystyczne dla poszczególnych grup czasowników lub jako jednostkowe przypadki warte przebadania w przyszłości.

\subsection{Zmiany walencji wywołane prefiksacją}

Jak to zostało pokazane na wykresie (por. s. 482), opisując zmiany walencji czasowników wywołane prefiksacją, braliśmy pod uwagę wyłącznie zmiany formalne, dotyczące liczby pozycji otwieranych przez verbum, ich konfiguracji i wartości kategorialnej, a także występowanie konstrukcji analitycznej w miejscu formy syntetycznej przypadka lub odwrotnie. W wypadku pojawienia się w miejscu argumentu konstrukcji analitycznych ważne było również stwierdzenie, czy wystąpiło w nich zjawisko reduplikacji prefiksu lub jakiekolwiek ograniczenie zbioru przyimków tworzących wyrażenia, dla których otwierał miejsce nowo powstały czasownik.

W przeciwieństwie do derywatów czasownikowych dziedziczących charakterystykę walencyjną po swoich podstawach słowotwórczych, czasowniki, które w wyniku prefiksacji zmieniają swoje wymagania walencyjne, są w języku polskim tworzone przez ograniczoną liczbę prefiksów. D. Buttler nazywa te prefiksy „Czynnymi składniowo” i dzieli je na 3 grupy: 
a) prefiksy tranzytywizujące, które przekształcają czasowniki bezdopełnieniowe na przechodnie, ponieważ otwierają $\mathrm{w}$ ich kontekście nową pozycję dla rzeczownika w bierniku, np.

wy- $\quad$ stać $\rightarrow$ wystać coś; pracować $\rightarrow$ wypracować coś, służyć $\rightarrow$ wysłużyć coś;

od(e)- $\quad$ spać $\rightarrow$ odespać coś, pracować $\rightarrow$ odpracować coś, służyć $\rightarrow$ odsłużyć coś

za- $\quad$ krwawić $\rightarrow$ zakrwawić coś; chlapać $\rightarrow$ zachlapać coś

o(b)- $\quad$ biec $\rightarrow$ obiec coś; klaskać $\rightarrow$ oklaskać coś (kogoś)

b) prefiksy rozszerzające, które po dodaniu do czasownika tworzą derywat otwierający dodatkową pozycję w stosunku do schematu walencyjnego podstawy słowotwórczej dla dopełnienia dalszego lub dla określeń miejsca, np.

o(b)-, otwierający dodatkową pozycję narzędnikową (obok biernikowej), np. budować coś $\rightarrow$ obudować coś czymś

prze-, otwierający oprócz biernika dziedziczonego po podstawie słowotwórczej dwie dodatkowe pozycje, np. nieść coś $\rightarrow$ przenieść cośs skądś dokądś

przedrostki kierunkowe do-, od-, z-, które wpływają na pojawienie się dodatkowej pozycji dla określenia miejsca, np. issć $\rightarrow$ dojść dokądś, odejść skądś, zejść skądś

c) prefiksy modyfikujące, które nie zmieniają liczby pozycji otwieranych przez nowo powstały czasownik, ale zmieniają postać morfologiczną członu dopełnieniowego, np. stuchać czegoś - przesłuchać coś. W zależności od tego, jaki przypadek narzuca prefiks modyfikujący członowi konotowanemu przez derywat czasownikowy, autorka wyróżnia 3 typy takich przedrostków: akuzatywne, genetywne i datywne.

Analiza zebranego materiału potwierdziła zasadność podziału prefiksów zaproponowanego przez D. Buttler. W naszym opracowaniu przedmiotem klasyfikacji są jednak nie prefiksy, ale zmiany walencji przez prefiksy wywoływane. $\mathrm{W}$ pierwszej fazie opisu zostały one podzielone na dwie grupy: pierwsza $\mathrm{z}$ nich obejmuje zmiany dotyczące liczby i konfiguracji pozycji otwieranych przez czasownik, druga zaś zmiany, które dotyczą formy w obrębie tej samej pozycji. W kolejnych podziałach zostały wyodrębnione zmiany ilościowe i jakościowe oraz ich zróżnicowanie ze względu na wymagania składniowe derywatów prefiksalnych w stosunku do czasownika bazowego. W efekcie wyodrębniono 9 rodzajów zmian walencji, które może wywoływać w języku polskim prefiksacja. W dalszej części artykułu każdy z nich zostanie zilustrowany przykładami typów słowotwórczych, dla których opisywana zmiana jest charakterystyczna. Zostanie także podjęta próba uzasadnienia danej zmiany przez wskazanie pola leksykalnego, do którego został włączony derywat w wyniku prefiksacji i tym samym zmuszony do przyjęcia nowego schematu składniowego. 


\subsubsection{Zwiększenie się liczby pozycji otwieranych przez czasownik bez mo- dyfikacji pozycji dziedziczonych}

Zyskiwanie dodatkowej pozycji walencyjnej w stosunku do czasownika bazowego jest $\mathrm{w}$ języku polskim charakterystyczne dla różnych semantycznych grup derywatów czasownikowych. Jedną z nich są czasowniki ruchu, które jako podstawy otwierają miejsce tylko dla subiekta, natomiast po dodaniu prefiksu pojawia się przy utworzonych $\mathrm{w}$ ten sposób derywatach dodatkowy argument lokatywny o postaci wyrażenia przyimkowego, w którym przyimek jest tożsamy funkcjonalnie z prefiksem, czyli pełni funkcje takie jak np.

ablatywną: chodzić $\rightarrow$ wychodzić $z+$ gen.; biec - wybiec $z+$ gen;

adlatywną: chodzić $\rightarrow$ wchodzić do + gen; biec - wbiec do + gen;

perlatywną: chodzić $\rightarrow$ przechodzić przez + acc; biec - przebiec przez + acc.

Zdarza się również, że derywaty prefiksalne, których bazą jest czasownik ruchu, mają zupełnie inne znaczenie niż ich podstawy, czego sygnałem jest dodatkowy argument o postaci rzeczownika w bierniku, np.

chodzić $\rightarrow$ wychodzić + acc, np. wychodzić stypendium

jeździć $\rightarrow$ przejeździć + acc, np. przejeździć pieniądze

jechać $\rightarrow$ objechać + acc, np. objechać miasto

Taka zmiana walencji derywatu w stosunku do czasownika bazowego, której towarzyszy modyfikacja znaczenia, pojawia się także w grupie polskich czasowników, oznaczających znajdowanie się w jakimś stanie, np.

chorować $\rightarrow$ odchorować stratę

płakać $\rightarrow$ wypłakać oczy

pracować $\rightarrow$ wypracować koncepcje

chorować $\rightarrow$ przechorować wakacje

jeździć $\rightarrow$ zajeździć samochód

W podziale D. Buttler należą one do derywatów utworzonych przez wymienione wyżej prefiksy tranzytywizujące, czyli takie, które przekształcając czasowniki nieprzechodnie na przechodnie, otwierają obligatoryjnie dodatkową pozycję dla dopełnienia bliższego w bierniku, rzadziej w dopełniaczu.

Jak widać, wywołane prefiksacją zwiększenie się liczby pozycji otwieranych przez czasownik bez modyfikacji pozycji dziedziczonych po podstawie słowotwórczej jest bardzo częste w polszczyźnie i dość regularne. Wywołują je najczęściej prefiksy wprowadzające nowo utworzony czasownik do pola leksykalnego obejmującego verba $\mathrm{z}$ obligatoryjnym komponentem różnego typu aktualizacji czasowej lub przestrzennej, który w zdaniu pojawia się jako okolicznik czasu lub miejsca ${ }^{1}$, np.

1 Autorzy niektórych opracowań proponują, aby traktować je jako dopełnienia dalsze, a nie okoliczniki, gdyż są konotowane przez czasownik (Gołąb, s. 22; Wróbel 1976, s. 179). 
siedzieć $\rightarrow$ dosiedzieć do rana, wysiedzieć dwie godziny, odsiedzieć godzinę, posiedzieć trochę, przesiedzieć całą noc

jechać $\rightarrow$ dojechać do celu, wyjechać z Krakowa, odjechać z miejsca wypadku, wjechać do garażu, rozjechać się do domów

Dodatkowe miejsce otwierane przez tego typu czasowniki dla leksemów o znaczeniu ograniczającym akcję czasowo lub przestrzennie jest wbudowane w strukturę semantyczną tych czasowników ze względu na obecność prefiksu, który wywodzi się historycznie z tego samego źródła, co odpowiadający mu przyimek. To wspólne pochodzenie sprawia, że prefiks pełni w wielu wypadkach taką samą funkcję, jak przyimek stanowiący człon konstytutywny wyrażenia przyimkowego, pojawiającego się przy czasowniku z prefiksem jako dodatkowa obligatoryjna pozycja także o znaczeniu innym niż czasowe lub przestrzenne. Czasami dochodzi w takich wypadkach do całkowitej reduplikacji postaci prefiksu, np.

$$
\begin{aligned}
& \text { robić klucz } \rightarrow \text { dorobić klucz do czegoś } \\
& \text { dzielić coś } \rightarrow \text { oddzielić coś od czegoś } \\
& \text { wiązać coś } \rightarrow \text { związać coś z czymś } \\
& \text { pchać coś } \rightarrow \text { zepchnąć coś z czegoś }
\end{aligned}
$$

Wszystkie typy słowotwórcze, w których dodanie prefiksu zwiększa liczbę pozycji otwieranych przez czasownik przy zachowaniu formy pozycji dziedziczonych, są dziś bardzo produktywne. Szczególnie liczne są derywaty utworzone od czasowników oznaczających wydawanie różnego typu głosów przez ludzi lub zwierzęta. Dodany do tych czasowników prefiks tranzytywizujący tworzy derywaty należące do pola semantycznego czasowników mówienia, co sprawia, że otwierają obligatoryjnie pozycję dla dopełnienia bliższego w bierniku², np.

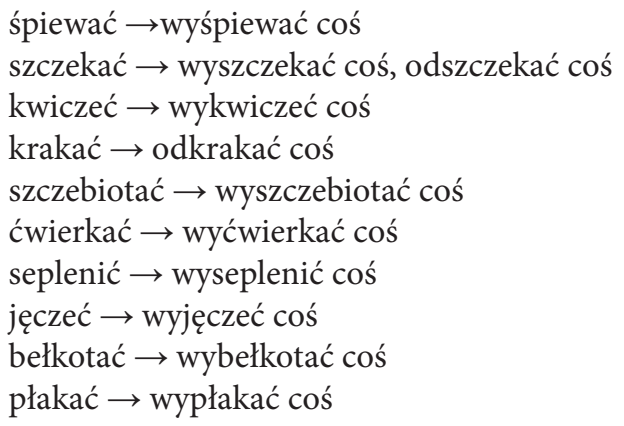

Także wiele neologizmów czasownikowych pojawiających się w internecie, z których część jest wymieniana w pracach poświęconych nowemu polskiemu słownictwu, powstało w wyniku prefiksacji wpływającej na zwiększenie liczby pozycji walencyjnych. Na uwagę zasługuje w szczególności częste dublowanie ich

2 Część przytoczonych niżej przykładów pochodzi z: Wierzchoń 2007. 
prefiksu w postaci przyimka pojawiającego się w dodatkowej pozycji otwieranej przez derywat, np.

dokimać do rana (https://forum.gazeta.pl)

dofinansować do 65 proc. składki ubezpieczenia upraw rolnych (https://finanse.wp.pl/ sejm)

odjeb się od mojego brata (https://pl.glosbe.com)

odganiać się od pomocy (https://forum.gazeta.pl)

wjarał się w jakieś gówno (www.mypolacy.de)

Wszystko to wskazuje na dużą regularność zmian polegających na zwiększaniu liczby pozycji walencyjnych w wyniku prefiksacji. Dodatkowe pozycje są przy tym zwykle narzucane przez schematy walencyjne przypisane do nowych pól leksykalnych, do których prefiks wprowadza czasownik podstawowy ze względu na swoją funkcję tranzytywizującą lub modyfikującą czasowo bądź przestrzennie akcję nazwaną przez verbum.

\subsubsection{Zwiększenie się liczby pozycji otwieranych przez czasownik z modyfi- kacją pozycji dziedziczonych}

Derywatów, w których prefiks zmienił schemat walencyjny w stosunku do podstawy słowotwórczej w taki sposób, że zwiększyła się liczba pozycji otwieranych przez czasownik, przy czym w pozycjach dziedziczonych po podstawie zmieniła się forma składnika konotowanego, jest w polszczyźnie sporo, ale tworzą one niewielką liczbę typów słowotwórczych.

Należą do nich m.in. czasowniki nazwane w GWJP transformatywnymi (s. 560). Oznaczają nadawanie obiektowi czynności nazwanej podstawą, wyrażonemu przez dopełnienie bliższe w bierniku, funkcji semantycznej przeznaczenia pełnionej przez wyrażenie przyimkowe, a jednocześnie otwierają miejsce dla nowego obiektu czynności, np.

budować garaż $\rightarrow$ przebudować piwnicę na garaż

Typ słowotwórczy reprezentowany przez powyższy przykład jest dziś na tyle produktywny, że powstające nowe derywaty czasownikowe z prefiksem prze-często przyjmują opisany wyżej schemat walencyjny charakterystyczny dla pola leksykalnego czasowników oznaczających przekształcanie czegoś na coś innego ${ }^{3}$, np.

projektować galerię handlową $\rightarrow$ przeprojektować starą fabrykę na galerię handlową robić miejsce do spania $\rightarrow$ przerobić tylne siedzenie na miejsce do spania

3 O derywatach tego typu wspomina H. Wróbel w GWJP (s. 560) oraz M. Wiśnicki (s. 143), który traktuje je jako efekt derywacji wymiennej zbudować - przebudować. Jako dowód ich dużej produktywności podaje, że w Słowniku gniazd słowotwórczych współczesnego języka polskiego jest ich 110 . 
Ciekawe są pod tym względem teksty z dziedziny rachunkowości, w których argumentami przy wielu czasownikach z prefiksem prze- są nazwy pozycji uwzględnianych w dokumentacji ekonomiczno-finansowej, np.

przeksięgować zysk na kapitał zapasowy spółki (www.spolkowy.pl)

przeksięgować kwotę na wpływy z innych źródeł (www.vademecumksiegowego.pl)

przepisać darowizny na przychody z innych źródeł (https://ksiegowosc.infor.pl)

przewalutować kredyt we frankach na złotówki (https://frankowicze.net)

Inny typ słowotwórczy, w którym prefiksacja wpływa na opisywany rodzaj zmian walencji, tworzą czasowniki oznaczające ruch w kierunku kogoś lub czegoś uniemożliwiający osiągnięcie miejsca czynności nazwanej podstawą, np.

biec drogą $\rightarrow$ zabiec komuś drogę

Dodatkową pozycją jest w tym wypadku rzeczownik w celowniku stanowiący dopełnienie dalsze nazywające odbiorcę czynności. Pozycją dziedziczoną jest natomiast argument pełniący funkcję lokalizatora przestrzennego, który zmienia swoją formę z narzędnikowej na biernikową.

Ta sama funkcja semantyczna prefiksu może jednak powodować zwiększenie się liczby otwieranych pozycji bez zmiany formy pozycji dziedziczonej, np.

grodzić przejście $\rightarrow$ zagrodzić komuś przejście

tarasować przejazd $\rightarrow$ zatarasować komuś przejazd

Ostatnie dwa przykłady wskazują na mniej istotne znaczenie, jakie ma dla opisywanego zjawiska forma składników w pozycjach dziedziczonych po podstawie. Ważniejsza bowiem okazuje się w tym wypadku większa liczba pozycji otwieranych przez nowo powstały czasownik.

\subsubsection{Zmniejszenie się liczby pozycji otwieranych przez czasownik}

Czasowniki, które jako jedyne pod wpływem prefiksu mogą nie tylko zwiększać liczbę otwieranych pozycji, ale także zmniejszać liczbę konotowanych miejsc, to czasowniki ruchu. Każdy z nich nazywając poruszanie się w przestrzeni, otwiera fakultatywnie miejsca dla punktu początkowego ruchu, jego punktu końcowego, a często także dla drogi, po której ruch się odbywa. Prefiksacja ogranicza te możliwości walencyjne do jednej tylko pozycji, uwarunkowanej znaczeniem prefiksu, np.

jechać z Krakowa do Warszawy przez Kielce $\rightarrow$ odjechać $\mathrm{z}$ Krakowa, dojechać do Warszawy, przejechać przez Kielce

biec $\mathrm{z}$ domu do lasu przez pole $\rightarrow$ wybiec $\mathrm{z}$ domu, dobiec do lasu, przebiec przez pole

Poza tą grupą czasowników zmniejszenie się liczby pozycji konotowanych $\mathrm{w}$ wyniku prefiksacji jest $\mathrm{w}$ języku polskim stosunkowo rzadkie. $\mathrm{Z}$ sytuacją taką 
mamy do czynienia jedynie w nielicznych derywatach starych, których związek z podstawą rozluźnił się lub które uległy częściowej leksykalizacji, np.

dać coś komuś $\rightarrow$ nadać coś (nadać paczkę, nadać list)

mówić coś komuś $\rightarrow$ wymówić coś (wymówić głoskę, słowo), przemówić do kogoś

\subsubsection{Zmiana formy i konfiguracji pozycji otwieranych przez czasownik.}

Skomplikowaną zmianą schematu walencyjnego podstawy, pojawiającą się jako wynik prefiksacji, jest jednoczesna modyfikacja formy składników konotowanych przez czasownik i ich konfiguracji wewnątrz schematu. H. Wróbel (1976, 1978, 1998) opisując ten typ przekształceń walencyjnych, tłumaczył je zmianami odniesienia przedmiotowego akcji w strukturze formalnej zdania, polegającymi na tym, że:

a) określenie lokalne przekształca się na dopełnienie bliższe, a przedmiot objęty działaniem akcji podstawowej staje się jednocześnie dopełnieniem dalszym, przy czym przedrostki wnoszą do znaczenia derywatu swoją treść lokalną (lokalizującą obiekt na powierzchni lub dookoła niej) (Wróbel 1978, s. 179, GWJP, s. 558), np.

lać wodę na podłogę $\rightarrow$ zalać podłogę wodą sypać cukier na placek $\rightarrow$ posypać placek cukrem sadzić żywopłot wkoło ogrodu $\rightarrow$ obsadzić ogród żywopłotem

b) określenie miejsca akcji zajmuje pozycję podmiotu gramatycznego, a podmiot czasownika bazowego pełni przy derywacie funkcję dopełnienia dalszego, nazywając środek czynności (Wróbel 1978, s. 179), np.

Szuwary rosły na stawie $\rightarrow$ Staw zarósł szuwarami

Bluszcz rósł dookoła altany $\rightarrow$ Altana obrosła bluszczem

c) jeden z obiektów pozostających na dalszym planie zostaje przesunięty do pozycji obligatoryjnego dopełnienia biernikowego, przez co derywat jest zawsze przechodni, niezależnie od charakterystyki walencyjnej podstawy (GWJP, s. 553, Stawnicka 2019, s. 85), np.

Jan darował Marii książkę $\rightarrow$ Jan obdarował Marię książką

Złodziej ukradł (wszystkie) pieniądze gospodarzowi $\rightarrow$ Złodziej okradł gospodarza z pieniędzy

Piotr grał $\mathrm{z}$ Janem w pokera $\rightarrow$ Piotr ograł Jana w pokera

Jan rzucił wyzwiska w stronę Marii $\rightarrow$ Jan obrzucił Marię wyzwiskami

Oprócz wymienionych typów słowotwórczych opisywana zmiana dotyczy kilku formacji nazywających uzyskanie czegoś, np.

prosić kogoś o coś $\rightarrow$ wyprosić coś u kogoś 
zlikwidowanie przyczyny czegoś, co nazywa dopełnienie dalsze występujące przy podstawie, np.

pić wino ze zmartwienia $\rightarrow$ zapić zmartwienie winem

oraz rozdzielenie tego, na co wskazuje podstawa przez zamianę podmiotu gramatycznego na dopełnienie bliższe

działka graniczy z placem zabaw $\rightarrow$ odgraniczyć działkę od placu zabaw

drukarka łączy się z komputerem $\rightarrow$ odłączyć drukarkę od komputera

Przytoczone przykłady świadczą o dużej różnorodności przesunięć w konfiguracji pozycji otwieranych przez czasownik pod wpływem prefiksacji. Wszystkie te zmiany są przy tym bardzo regularne, ale nieliczne, ponieważ zależne nie tylko od prefiksu, lecz również od znaczenia podstawy.

\subsubsection{Zmiana formy przypadka $w$ pozycji otwieranej przez czasownik dla formy syntetycznej}

Zmiany formy przypadka w obrębie tej samej pozycji otwieranej przez czasownik są w języku polskim na tyle regularne, że można doszukiwać się w nich pewnego rodzaju kategorialności. Najczęściej chodzi o zastąpienie rekcji biernikowej dopełniaczową, co jest związane z funkcją partytywności charakterystyczną dla polskiego genetivu, wprowadzaną przez niektóre prefiksy, w szczególności przez prefiks do-. Z tego właśnie powodu D. Buttler uznała do- za przedrostek genetywny, który był licznie reprezentowany w badanym przez nas materiale, np.

kupić coś $\rightarrow$ dokupić czegoś

sypać coś $\rightarrow$ dosypać czegoś

dać coś $\rightarrow$ dodać czegoś

drukować coś $\rightarrow$ dodrukować czegoś

zbierać coś $\rightarrow$ dozbierać czegoś

Wszystkie przytoczone wyżej czasowniki należą do licznej w języku polskim kategorii słowotwórczej czasowników oznaczających dodawanie czegoś do czegoś, która wiąże się zwykle z partytywnością. Analiza zebranego materiału wykazała jednak, że w tekstach współczesnych przy czasownikach należących do tej kategorii słowotwórczej jest o wiele częściej stosowany biernik niż dopełniacz, np.

Musieliśmy dodrukować książki i inne materiały.

Trzeba dokupić owoce, bo nie starczy na kompot.

Także wśród nowych formacji czasownikowych należących do tej kategorii słowotwórczej przeważa walencja biernikowa, np.

Musieliśmy dokserować materiały, bo nie starczyło dla wszystkich. 
Niewątpliwie jest to związane z silną we współczesnej polszczyźnie tendencją do wypierania dopełniacza przez biernik. Jej potwierdzeniem był również analizowany przez nas materiał, w którym czasowniki z prefiksem do- rzadko przyjmowały rekcję dopełniaczową. Dotyczy to także nowych formacji prefiksalnych, wśród których tylko dwie otwierały miejsce dla dopełniacza ${ }^{4}, \mathrm{np}$.

dozbierać brakujących głosów (https://natemat.pl/)

dodłubać aniołków na sprzedaż (https://www.maluchy.pl/forum)

W grupie derywatów czasownikowych, które w wyniku prefiksacji zmieniły wartość kategorii przypadka, przysługującą składnikowi w pozycji konotowanej przez czasownik bazowy, pojawiły się w badanym materiale także formacje z prefiksami wy- oraz za-, tworzące kategorię słowotwórczą czasowników nazywających całkowite zużycie przedmiotu (GWJP, s. 559). Przedmiotem tym jest środek czynności, którego nazwa przy czasowniku będącym podstawą słowotwórczą występuje na ogół w narzędniku, np.

$$
\begin{aligned}
& \text { pisać długopisem } \rightarrow \text { wypisać długopis } \\
& \text { szyć nićmi } \rightarrow \text { wyszyć nici } \\
& \text { jeździć samochodem } \rightarrow \text { zajeździć samochód }
\end{aligned}
$$

Na zmianę walencji w tej grupie czasowników prefiksalnych zwracał uwagę w swoich pracach $\mathrm{H}$. Wróbel, który wyjaśniał ją semantycznie, przypisując formantowi o znaczeniu 'zużyć' funkcję narzucania derywatom konotacji nazwy zużywanego obiektu, który przy czasowniku podstawowym pełni rolę instrumentu, a przy derywacie jest członem pojawiającym się obligatoryjnie w accusativie jako dopełnienie bliższe (GWJP, s. 559). Tezę tę potwierdzają przykłady, w których nazwa zużytego środka czynności występuje przy czasowniku bazowym w innym przypadku niż instrumentalis lub w ogóle nie występuje ${ }_{2}$ a mimo to prefiks narzuca tworzonemu derywatowi rekcję biernikową, np.

nosić spodnie $\rightarrow$ znosić spodnie

jeździć na nartach $\rightarrow$ zjeździć narty

płakać $\rightarrow$ wypłakać oczy

Za motywacją formalną przemawia z kolei to, że formanty tworzące tę kategorię słowotwórczą to wyłącznie prefiksy wy-, z- i za-, które w klasyfikacji D. Buttler należą wszystkie do grupy przedrostków akuzatywnych.

\subsubsection{Zmiana formy $z$ liczby pojedynczej na mnogą w pozycji otwieranej przez czasownik dla formy syntetycznej}

Zmiany walencji wywołane prefiksacją polegają nie tylko na zmianie przypadka gramatycznego w obrębie pozycji otwieranej przez czasownik, ale także na

4 Jest ich także bardzo mało w materiale prezentowanym w: Wierzchoń 2007 
zmianie wartości kategorii liczby. Również ta zmiana prowadzi niejednokrotnie do ujednolicenia wymagań walencyjnych derywatu mimo różnych form wymaganych przez jego podstawę. W wielu wypadkach, kiedy chodzi o liczbę, prefiks powoduje, że zawierający go czasownik wymaga obligatoryjnie liczby mnogiej, chociaż podstawa słowotwórcza może dopuszczać obie formy - singularis i pluralis, np.

łapać muchę/muchy $\rightarrow$ wyłapać muchy

burzyć dom/domy $\rightarrow$ poburzyć domy

zmywać talerz/talerze $\rightarrow$ nazmywać talerzy

Autorzy prac poświęconych derywacji czasownikowej tłumaczą tę zmianę względami semantycznymi, uwarunkowanymi funkcją znaczeniową prefiksu po-, który dodany do niektórych czasowników tworzy derywaty o znaczeniu dystrybutywnym i wtedy w sposób regularny zmienia formę z liczby pojedynczej na mnogą otwieranego przez nie miejsca dla podmiotu $\mathrm{w}$ mianowniku, np.

złodziej ucieka/ złodzieje uciekają $\rightarrow$ złodzieje pouciekali

lub dla dopełnienia w bierniku, np.

budzić sąsiada/budzić sąsiadów $\rightarrow$ pobudzić sąsiadów

przesadzać kwiat/poprzesadzać kwiaty $\rightarrow$ poprzesadzać kwiaty

Prefiks po- zmienia też liczbę pojedynczą na mnogą rzeczownika zajmującego pozycję dopełnienia przy czasownikach, które wskutek prefiksacji zyskują znaczenie wielokrotności akcji, np.

rozbijać talerz $\rightarrow$ porozbijać talerze

zjadać resztkę ciasta $\rightarrow$ pozjadać resztki ciasta

Wartość kategorii liczby zmienia się obligatoryjnie na pluralis także pod wpływem prefiksów tworzących formacje kompletywne (GWJP s. 549), np.

gasić światło/światła $\rightarrow$ wygasić światła

łapać zająca/zające $\rightarrow$ wyłapać zające

$\mathrm{Na}$ ograniczenie wartości kategorii liczby wyłącznie do liczby mnogiej wpływa też prefiks roz-, tworząc derywaty oznaczające wyczerpanie zasobu czegoś, np.

dać prezent/prezenty $\rightarrow$ rozdać prezenty

kupić rower/rowery $\rightarrow$ rozkupić rowery

Typy słowotwórcze, w których pod wpływem prefiksacji otwierana jest pozycja dopełnienia wyłącznie dla rzeczowników w liczbie mnogiej, są dziś bardzo produktywne (por. Wierzchoń 2007). Wśród nowych formacji prefiksalnych często są $\mathrm{w}$ tej funkcji wykorzystywane prefiksy po- i na-, np. 
angażować statystę/statystów $\rightarrow$ poangażować statystów (Wierzchoń 2007) wyrzucać $\mathrm{z}$ pracy ajenta/ajentów $\rightarrow$ powyrzucać $\mathrm{z}$ pracy ajentów (https://natemat.pl) dolepiać sztuczną brodę/sztuczne brody $\rightarrow$ podolepiać sztuczne brody (https:// pl.glosbe.com) nawracać polityka/polityków $\rightarrow$ ponawracać polityków (https://wiadomosci.wp) wtykać szpilkę/szpilki $\rightarrow$ nawtykać szpilek (https://books.google.pl/) trzaskać medal/medale $\rightarrow$ natrzaskać medali (Wierzchoń 2007) uchwalać ustawę/ustawy $\rightarrow$ nauchwalać ustaw (Wierzchoń 2007) wręczać sobie odznaczenie/odznaczenia $\rightarrow$ nawręczać sobie odznaczeń (Wierzchoń 2007)

\subsubsection{Zmiana przyimka w obrębie tej samej pozycji}

Wiele polskich czasowników konotuje wyrażenie przyimkowe, które może w języku polskim odnosić się do lokalizatora temporalnego lub przestrzennego, może także wyrażać przyczynę, skutek, cel lub sposób wykonywania czynności oraz pełnić inne funkcje semantyczne.

Prefiks dodawany do takich czasowników wpływa czasami na zmianę przyimka w konotowanym wyrażeniu. Powodem może być modyfikacja znaczenia podstawy, która włącza derywat czasownikowy do pola leksykalnego o innej charakterystyce walencyjnej, np. przyczyna czynności jest często nazywana wyrażeniem przyimkowym z przyimkiem $z a$ i dlatego jest ono wymagane przez czasowniki oznaczające wykonywanie czynności z jakiejś przyczyny, np. pić za czyjeś zdrowie, wyjechać za czyją́ zgodą. Jeśli więc prefiks nadaje derywatowi takie znaczenie, $\mathrm{w}$ jego schemacie walencyjnym pojawia się przyimek $z a$ także wtedy, kiedy schemat podstawy słowotwórczej zawierał inny przyimek, np.

prosić o coś $\rightarrow$ przeprosić za coś

dążyć do czegoś $\rightarrow$ podążać za czymś

Zmiana przyimka w pozycji otwieranej przez czasownik może być także spowodowana silną w języku polskim tendencją do reduplikacji prefiksu, który swoją postać dubluje w postaci przyimka, np.

siąść na coś $\rightarrow$ zsiąść z czegoś

łączyć coś z czymś $\rightarrow$ dołączyć coś do czegoś

prowadzić coś $\rightarrow$ doprowadzić do czegoś

prowadzić coś $\rightarrow$ naprowadzić na coś

dłubać w czymś $\rightarrow$ dodłubać się do czegoś 


\subsubsection{Zmiana formy składnika konotowanego $\mathrm{z}$ syntetycznej na analityczną}

Wiele zmian rekcji pojawiających się pod wpływem prefiksacji ma związek z obserwowaną od czasów staropolskich tendencją analityczną. ${ }^{5}$ To morfologiczno-składniowe zjawisko polega nie tylko na zastępowaniu form fleksyjnych przez konstrukcje analityczne, ale także na częstszym wybieraniu konstrukcji analitycznej jako wykładnika argumentu. Potwierdzeniem nasilania się tego procesu jest często występująca pod wpływem prefiksacji zmiana formy syntetycznej przypadka na wyrażenie przyimkowe w obrębie pozycji otwieranych przez czasownik, np.

nieść coś $\rightarrow$ donieść na kogoś/na coś

nieść coś $\rightarrow$ odnieść się do czegoś

mianować kimś $\rightarrow$ przemianować na kogoś

tykać czego $\rightarrow$ dotykać do czego/czego

Formantem wprowadzającym taką zmianę pozycji otwieranej przez czasownik bywa często cząstka się, nadająca czasownikowi dodatkowe znaczenie zwrotności, np.
twierdzić coś $\rightarrow$ utwierdzić się w czymś
palić coś $\rightarrow$ zapalić się do czegoś
łączyć coś $\rightarrow$ włączyć się do czegoś
poznać coś $\rightarrow$ zapoznać się z czymś
powołać kogoś $\rightarrow$ powołać się na kogoś
powiedzieć coś $\rightarrow$ opowiedzieć się za czymś

lub wzajemnościowe, np.

bić kogoś $\rightarrow$ bić się z kimś

kochać kogoś $\rightarrow$ kochać się z kimś

\subsubsection{Zmiana formy składnika konotowanego $z$ analitycznej na syntetyczną}

Oprócz tendencji analitycznej występuje w polszczyźnie także proces odwrotny, a mianowicie zmiana konstrukcji analitycznych na formy syntetyczne przypadka. Przykładów ilustrujących przekształcanie się wyrażeń przyimkowych w pojedyncze leksemy rzeczownikowe $\mathrm{w}$ określonym przypadku jest $\mathrm{w}$ języku polskim znacznie mniej niż zmian formy syntetycznej na konstrukcję analityczną. Nie dotyczy to jednak wywołanych prefiksacją zmian formalnych w obrębie pozycji otwieranych przez czasownik. Prefiksy akuzatywne, genetywne i datywne, a także te, które konotują instrumentalis bardzo często zmieniają rekcję czasownika z przyimkowej na syntetyczną. Dotyczy to m.in. czasowników typu verba dicendi

5 O tendencji analitycznej w języku polskim por. m, in. EJO, 42; Anusiewicz 1978; Jabłońska 2020; Kempf 1962; Moszyński 2006. 
oraz verba sentiendi, w których prefiksacja zmienia formę składnika konotowanego na biernikową, np.

mówić o kimś $\rightarrow$ obmówić kogoś

gadać o kimś $\rightarrow$ obgadać kogoś

krzyczeć do kogoś $\rightarrow$ przekrzyczeć kogoś

błagać o coś $\rightarrow$ wybłagać coś

skarżyć się na coś $\rightarrow$ zaskarżyć coś (wyrok, ustawę)

myśleć o czymś $\rightarrow$ wymyślić coś (formacje wytwórcze)

marzyć o czymś $\rightarrow$ wymarzyć coś

pamiętać o czymś $\rightarrow$ zapamiętać coś

Zmiana taka pojawiła się w badanym materiale także w innych grupach derywatów czasownikowych, np.

pamiętać o czymś $\rightarrow$ zapamiętać coś

pracować na coś $\rightarrow$ odpracować coś

patrzeć na coś $\rightarrow$ wypatrzyć coś

Siła niektórych prefiksów akuzatywnych zdecydowała również o zmianie rekcji z przyimkowej na biernikową w kilku neologizmach wymienionych przez P. Wierzchonia (2007, s. 184-185), np.

dyskutować o czymś (o radach nadzorczych) $\rightarrow$ wydyskutować coś (rady nadzorcze) kopulować z kimś $\rightarrow$ wykopulować kogoś

Z kolei wywołana prefiksacją zamiana wyrażenia przyimkowego na rzeczownik w celowniku lub narzędniku wystąpiła w mniejszej liczbie derywatów, ale tė̇ nie należała do rzadkości, np.

machać do kogoś $\rightarrow$ odmachać komuś

patrzeć na kogoś $\rightarrow$ przypatrzyć się komuś

cieszyć się z czegoś $\rightarrow$ pocieszyć się czymś

wybrać na kogoś $\rightarrow$ obrać kimś

\section{Podsumowanie}

Przeprowadzona $\mathrm{w}$ artykule analiza czasownikowych formacji prefiksalnych wykazała, że zmiany schematu walencyjnego wywołane prefiksacją obejmują wszystkie możliwe $\mathrm{w}$ języku polskim przekształcenia formalne fraz konotowanych przez czasownik. Okazało się, że prefiks może wpływać zarówno na zwiększenie się lub zmniejszenie ich liczby, jak również na ich konfigurację i postać morfologiczną. Źródłem tych zmian bywa znaczenie wprowadzane przez prefiks

${ }^{6}$ Czasownik ten często $\mathrm{w}$ tekstach potocznych dziedziczy rekcję analityczną po podstawie, stając się przyczyną błędów składniowych (por. Jabłońska 2020). 
do struktury semantycznej czasownika lub typ prefiksu wyróżniony ze względu na narzucany przez ten prefiks przypadek.

W obu wypadkach prefiksacja powoduje włączenie nowo powstałego derywatu do określonego pola leksykalnego, które ma zwykle przypisaną charakterystykę walencyjną przejmowaną następnie przez ów derywat jako własną. $\mathrm{W}$ ten sposób na opisane $\mathrm{w}$ artykule zmiany walencji wpływa przede wszystkim znaczenie derywatu, które decyduje o jego przynależności do określonego pola leksykalnego, a które jest zależne zarówno od znaczenia podstawy słowotwórczej, jak i funkcji prefiksu. Bardzo często jest to znaczenie metaforyczne, które jednak dla innych leksemów z danego pola leksykalnego jest znaczeniem podstawowym. Nawet jeśli pod względem formalnym nie mają one nic wspólnego $\mathrm{z}$ danym prefiksem lub z prefiksacją jako taką, to ich schemat walencyjny przejmuje czasownik, którego znaczenie prefiks zmienił na przenośne, a dzięki zmianie walencji jego metaforyczność osłabia się w świadomości użytkowników języka i ulega on procesowi leksykalizacji.

Przykładów potwierdzających ten ciekawy proces można znaleźć w polszczyźnie sporo, także wśród formacji nowych, np. czasownik naprowadzić na coś utworzony od prowadzić do czegoś jest używany w znaczeniu metaforycznym 'zwrócić uwagę na coś' i dlatego jego walencja upodobniła się do wymagań składniowych czasowników należących do pola leksykalnego o tym znaczeniu, takich jak np. wskazać na coś. Podobnie derywat otrzymać coś z czegoś utworzony od czasownika trzymać coś pod wpływem prefiksu zyskał znaczenie metaforyczne 'uzyskać coś z czegoś' i przejął schemat walencyjny grupy czasowników o tym znaczeniu.

Przegląd wszystkich możliwych w polszczyźnie zmian walencji czasownika pod wpływem prefiksacji pozwolił także zauważyć, że nie zawsze są one wywoływane przez te same prefiksy i nie zawsze są przypisywane do tych samych kategorii słowotwórczych. Są jednak często zgodne z panującymi w języku polskim tendencjami rozwojowymi, np. $z$ tendencją analityczną i syntetyczną, a także z tendencją do ekonomiczności języka, która powoduje m.in. zmniejszenie liczby pozycji pod wpływem prefiksacji, lub z tendencją do precyzyjności środków językowych, która wpływa $\mathrm{z}$ kolei na zwiększenie liczby pozycji lub zmianę ich konfiguracji $\mathrm{w}$ schemacie walencyjnym.

Ważne okazało się także stwierdzenie, że prefiksacja w dalszym ciągu wywołuje opisane zmiany walencji i że ich efekty widać w całych seriach neologizmów czasownikowych. Pokazuje to skalę opisywanego zjawiska i jego przyczyny inne niż wyłącznie rodzaj prefiksu. 


\section{Bibliografia}

Agrell, S. (1918). Przedrostki postaciowe czasowników polskich. Warszawa.

Anusiewicz, J. (1978). Konstrukcje analityczne we współczesnym języku polskim. Wrocław.

Bartnicka, B. (1990). Trudności w nauczaniu aspektu czasowników. W: Tradycja i nowoczesność w nauczaniu cudzoziemców języka polskiego (47-62). Gdańsk.

Bogusławski, A. (1963). Czasowniki dokonane i niedokonane i ich stosunki wzajemne, Z polskich studiów slawistycznych, Seria 2, Językoznawstwo. Warszawa, 153-159.

Bogusławski, A. (1963). Prefiksacja czasownikowa we współczesnym języku rosyjskim. Wrocław.

Buttler, D. (1976). Innowacje składniowe współczesnej polszczyzny (walencja wyrazów). Warszawa.

EJO - Encyklopedia językoznawstwa ogólnego. Wrocław, 1993.

Gladney, F.Y. (1963). Próba ekonomicznego opisu morfologii czasowników w języku polskim, Biuletyn PTJ, t. 22, 55-61.

Gołąb, Z. (1967). Próba klasyfikacji syntaktycznej czasowników polskich (na zasadzie konotacji), Biuletyn PTJ, nr 25, 3-43.

Jabłońska, M. (2020). Nowe przyimkowe konstrukcje analityczne w polszczyźnie przełomu XX i XXI wieku. Warszawa.

Kempf, Z. (1962). Od przypadka do przyimka, Zeszyty Naukowe WSP w Opolu. Językoznawstwo, 13-36.

Krupianka, A. (1969). Formacje czasownikowe z przedrostkiem o-(ob.-) w języku polskim. Toruń.

Kudra, B. (1993). Wpływ przedrostków na łączliwość składniową czasowników ruchu. Łódź: UŁ.

Kudra, B. (1995). Nowe derywaty czasownikowe, Acta Universitatis Lodziensis. Folia Linguistica 34, 51-60.

Lachur, Cz. (2008). O podstawach teoretycznych semantycznej kategorii ablatywności w językach słowiańskich, Acta Polono-Ruthenica XIII, 437-446.

Moszyński, L. (2006). Wstęp do filologii słowiańskiej. Warszawa.

SJPDor. - Słownik języka polskiego, Doroszewski, W. (red.). t. 1-11. Warszawa, 1958-1969.

Stawnicka, J. (2019). Czasownikowe formanty modyfikacyjne w języku polskim, Studia z Filologii Polskiej i Słowiańskiej 45. Warszawa, 81-97.

Szupryczyńska, M. (1973). Syntaktyczna klasyfikacja czasowników przybiernikowych. Warszawa-Poznań.

Śmiech, W. (1986). Derywacja prefiksalna czasowników polskich. Łódź.

Wierzchoń, P. (2007). W poszukiwaniu czasowników nieznanych lingwist(k)om. P. Nowak, P. Nowakowski (red.), Language, Communication, Information, $\mathrm{nr}$ 2, 149-197.

Wiśnicki, M. (2009). Derywacja prefiksalna wymienna w czasownikach polskich (w świetle danych gniazdowych), LingVaria, nr 1 (7), 139-150. 
Wróbel, H. (1976). Prefiksacja czasowników a aktualizacja struktur predykatowo-argumentowych. W: Otázky slovanské syntaxe IV/1 (175-180). Brno.

Wróbel, H. (1978). O zasadach opisu słowotwórczego polskich czasowników prefiksalnych, Studia gramatyczne II. Wrocław, 109-110.

Wróbel, H. (1998). Słowotwórstwo czasowników. W: Gramatyka współczesnego języka polskiego. Morfologia (536-583), t. II, (red.) R. Grzegorczykowa, R. Laskowski, H. Wróbel. Warszawa.

Wtorkowska, M. (2004). Funkcje prefiksu w(e)- w polskich formacjach czasownikowych, Jezikoslovni zapiski, nr 10, 59-69.

\title{
Strony internetowe:
}

https://forum.gazeta.pl

https://finanse.wp.pl/sejm

https://pl.glosbe.com

https://forum.gazeta.pl

www.mypolacy.de

www.spolkowy.pl

www.vademecumksiegowego.pl

https://ksiegowosc.infor.pl

https://frankowicze.net

https://natemat.pl

https://www.maluchy.pl/forum

https://natemat.pl

https://pl.glosbe.com

https://wiadomosci.wp

https://books.google.pl

\begin{abstract}
ABSTRAKT: W artykule zostały opisane wszystkie występujące w języku polskim zmiany schematów walencyjnych wywołane prefiksacją. Analiza kilkuset czasowników pozwoliła na wyodrębnienie wśród nich takich, które dziedziczą schemat walencyjny po swoich podstawach słowotwórczych i 9 typów derywatów, które zmieniają swoje wymagania walencyjne po dodaniu do nich prefiksu. Zmiany te dotyczą liczby otwieranych pozycji, ich konfiguracji oraz postaci morfologicznej. Ich źródłem jest najczęściej znaczenie wprowadzane przez prefiks do struktury semantycznej czasownika lub typ prefiksu wyróżniony ze względu na narzucany przez ten prefiks przypadek gramatyczny.
\end{abstract}

